\title{
KEPUASAN STAKEHOLDERS PAUD TERHADAP KINERJA LULUSAN PROGRAM STUDI S1 PGPAUD FIP UNY
}

Oleh:

Amir Syamsudin, Joko Pamungkas, \& Nurhayati,.

Pendidikan Anak Usia Dini, Universitas Negeri Yogyakarta

amirsyamsudin@uny.ac.id; joko_pamungkas@uny.ac.id; nurhayati@uny.ac.id

\begin{abstract}
Abstrak
Tujuan penelitian adalah untuk mengetahui tingkat kepuasan stakeholders PAUD atas kinerja lulusan program studi dan harapan stakeholders PAUD atas kinerja program studi S1 PGPAUD. Metode penelitian adalah survey terhadap stakeholders PAUD. Subjek penelitian sebanyak 48 orang lulusan program studi PGPAUD dan 48 orang kepala Taman Kanak-kanak yang tersebar di wilayah provinsi Daerah Istimewa Yogyakarta dan Jawa Tengah bagian selatan. Kriteria subjek penelitian adalah kepala TK dari lembaga PAUD yang mempekerjakan lulusan program studi S1 PGPAUD FIP UNY minimal sebanyak satu orang dengan masa kerja minimal satu tahun. Instrumen penelitian adalah angket terbuka. Teknik analisis data adalah deskriptif kuantitatif. Temuan hasil penelitian terbagi pada dua bagian. Bagian pertama tentang kepuasan stakeholders terhadap kinerja lulusan. Integritas kepribadian dan penguasaan teknologi informasi dari lulusan sangat memuaskan para stakeholders. Profesionalisme dalam bekerja dan kemampuan mengembangkan diri secara mandiri dari lulusan memuaskan para stakeholders. Kemampuan bekerjasama, berkomunikasi, dan penguasaan bahasa asing (Inggris) dari lulusan cukup memuaskan para stakeholders. Bagian kedua tentang kinerja program studi PGPAUD dalam menyelenggarakan pendidikan. Interaksi pembelajaran, lingkungan belajar, dan pengalaman belajar di program studi PGPAUD termasuk dalam kategori cukup memuaskan para lulusan. Ada hubungan positif antara pembelajaran selama kuliah di program studi PGPAUD dengan penguasaan kompetensi oleh lulusan. Bobot hubungan positif tersebut bersifat lemah karena lebih kecil dari kriteria $(0,487<0,500)$.
\end{abstract}

Kata Kunci: kepuasan stakeholders, lembaga PAUD, kinerja lulusan

\section{STAKEHOLDERS' SATISFACTION WITH THE PERFORMANCE OF GRADUATES FROM EARLY CHILDHOOD EDUCATION PROGRAMS AT EDUCATION FACULTY OF YOGYAKARTA STATE UNIVERSITY}

\begin{abstract}
The purpose of this research is to know the level of stakeholder's satisfaction on the performance of graduate and stakeholder's expectations on the performance of staff at the study program. The research method is survey. Research subjects were 48 graduates and 48 heads of kindergarten in the provinces of the Special Region of Yogyakarta and the south of Central Java. Criteria subject of research is the head of kindergarten from early childhood institutions that employ graduates and a minimum of one person with a minimum working period of one year. Data analysis technique is descriptive quantitative. The findings of the research are divided into two parts. The first part about stakeholders' satisfaction on the performance of graduates. Integrity of personality and mastery of information technology from graduates is very satisfying to the stakeholders.
\end{abstract}


Professionalism in work and self-development ability of graduates satisfy to the stakeholders. The ability to cooperate, communicate, and acquire foreign languages (English) from graduates is quite satisfactory to the stakeholders. The second part about the staff's performance in conducting education. Learning interaction, learning environment, and study experience in study program are included in the category of satisfactory to the graduates. There is a positive relationship between learning with competency of graduates. The weight of the positive relationship is weak because it is smaller than the criterion $(0.487<0.500)$.

Keywords: stakeholder's satisfaction, early childhood institutions, the performance of graduate.

\section{Pendahuluan dan Kajian Teori}

Perubahan merupakan hal yang niscaya dalam kehidupan manusia. Demikian pula orientasi pendidikan yang semula bertumpu pada asumsi ilmu untuk ilmu mengalami perubahan menjadi ilmu untuk kemanfaatan hajat hidup orang banyak. Pertanyaan yang sering muncul setelah seseorang menyelesaikan jenjang pendidikan tinggi ialah akan kerja apa, di mana, dan untuk siapa. Pertanyaan tersebut mengindikasikan perubahan kesadaran sekaligus harapan bahwa pengetahuan dan keterampilan yang diperoleh di bangku kuliah dapat bermanfaat bagi orang lain melalui karya nyata sang sarjana.

Demikian pula secara kelembagaan, lembaga pendidikan tinggi ditagih oleh stakeholders tentang kiprah nyata mencerdaskan generasi bangsa dalam wujud melahirkan lulusan yang berkualitas secara akademis maupun yang anggun kepribadiannya. Untuk melaksanakan cita-cita mulia tersebut, lembaga pendidikan dituntut untuk terus mereorganisasi dirinya dan meningkatkan kualitas layanan pendidikan kepada masyarakat. Salah satunya melalui penilaian kinerja program studi oleh Badan Akreditasi Nasional Perguruan Tinggi (BAN PT) dan penyusunan laporan Evaluasi Diri sebagai dasar pijakan konsolidasi organisasi dan pengembangan program kegiatan akademik.

Program studi PGPAUD telah meluluskan 536 orang lulusan sejak meluluskan 30 Agustus 2010 sampai dengan 31 Desember 2016 (Kemahasiswaan FIP UNY, 2017). Sebaran lulusan mayoritas berada di wilayah provinsi Daerah Istimewa Yogyakarta dan Jawa Tengah bagian Selatan.

Kinerja lulusan yang ditanyakan kepada stakholders dalam penelitian ini 
meliputi integritas kepribadian, berbasis internet, baik menggunakan penguasaan terhadap teknologi informasi, profesionalisme dalam bekerja, kemampuan mengembangkan diri, kemampuan bekerjasama, kemampuan berkomunikasi efektif, dan penguasaan bahasa asing (Inggris).

Integritas yang dimaksud dalam penelitian ini meliputi ciri-ciri perilaku tidak suka berbohong, selalu sabar dalam melaksanakan pekerjaan, siap menerima perubahan, memiliki motivasi yang tinggi, tekun dalam bekerja, dan menepati janji (AA Gea, 2006; Paul Suparno, SJ, 2015).

Penguasaan dan pemanfaatan teknologi informasi meliputi penggunaan komputer sebagai alat bantu pembelajaran, penggunaan internet sebagai sumber belajar anak usia dini, dan telephone seluler sebagai media komunikasi guru dengan orang tua anak (Syarifuddin, 2014). Penggunaan komputer dan internet meliputi kemampuan mengoperasikan computer, membuka lampiran kiriman dalam $e$ mail, penggunaan perangkat lunak antivirus, kemampuan mengunduh sumber belajar dari internet, mengoperasikan MS Word dan Excel, membuat grafik dan table, mengirim $e$ mail dan penggunaan jejaring social computer maupun handphone (Rusi Restiyani, dkk., 2014).

Profesional dalam bekerja dalam penelitian ini meliputi ciri menguasai materi pelajaran, memiliki keterampilan mengajar yang menyenangkan anak, memiliki strategi pemgelajaran yang bervaraitif, mampu merumuskan tujuan pembelajaran secara ringkas dan jelas, mampu merencanakan pembelajan, memiliki kemampuan manajerial kelas yang efisien, memiliki komitmen dan motivasi tinggi untuk membelajarkan anak (Dzulkifli dan Inda Puspita Sari, 2015; Pujiyana, 2012).

Kemampuan mengembangkan diri meliputi dapat bertindak atas inisitif sendiri, mudah bergaul dengan teman sejawat, memiliki sikap tenang dalam menghadapi masalah apa pun (Siti Amyani, 2010), melakukan pertimbangan kritis sebelum membuat keputusan, kreatif, dan mampu mengendalikan emosi (Lydia Ersta Kusumaingtyas, 2015).

Kemampuan bekerjasama dalam tim meliputi ciri-ciri perilaku saling berbagi tugas dalam menyelesaikan pekerjaan sesuai kapasitas masingmasing, mengerahkan segenap kemampuan untuk menjacapai tujuan 
bersama, merumuskan tujuan bersama, mengurangi kemalasan sosial dan menambah tanggung jawab individu, dan menumbuhkan saling percaya antara anggota tim (Dina Rolanna Simanungkalit dan Lucy Anna, 2012; Wahyu Kusuma Pratiwi dan Dwiarko Nugrohoseno).

Kemampuan berkomunikasi efektif meliputi ciri perilaku sopan dan santun dalam berbicara, mau mendengarkan lawan bicara, menunjukkan sikap terbuka dan hormat kepada pendengar, isi pembicaraan mudah dimengerti, suasana pembicaraan menyenangkan, peduli terhadap kebutuhan lawan bicara, terjadi hubungan yang akrab dan nyaman, dan berkeinginan untuk menjalin persahabatan (Hertina Wulansari, Tuti Hardjajani, Arista Adi Nugroho. t.t. versi online).

Kinerja program studi yang ditanyakan kepada lulusan dalam penelitian ini meliputi proses pembelajaran, lingkungan belajar yang kondusif, dan pengalaman belajar selama proses perkuliahan. Ketiga aspek tersebut dihimpun menjadi satu variable, yaitu pembelajaran. Persepsi lulusan terhadap proses pembelajaran dikorelasikan dengan penguasaan kompetensi setelah mereka lulus.

Metode

Jenis penelitian adalah survey. Metode penelitian menggunakan deskriptif kualitatif. Instrumen penelitian menggunakan angket terbuka. Subjek penelitian adalah lulusan PGPAUD dan kepala Taman Kanakkanak di wilayah provinsi DIY dan Jawa Tengah bagian Selatan yang mempekerjakan lulusan PGPAUD sebagai guru di lembaga pendidikan masing-masing.

Waktu penelitian dilaksanakan mulai Maret sampai dengan Desember 2016. Lokasi penelitian di wilayah provinsi DIY dan Jawa Tengah bagian Selatan. Subjek penelitian berjumlah 48 kepala Taman Kanak-kanak. Kriteria subjek penelitian adalah kepala Taman Kanak-kanak dari lembaga PAUD yang mempekerjakan lulusan minimal berjumlah satu orang dan minimal terikat kontrak kerja satu tahun.

Prosedur penelitian meliputi pengkajian teori tentang kepuasan kinerja, merumuskan definisi konseptual dan operasional, menyusun indikator kepuasan kinerja, merakit instrumen kepuasan kinerja dalam bentuk angket terbuka, merancang bentuk tabulasi data 
angket yang berjenis ordinal, pengumpulan data, reduksi dan tabulasi data, analisis data deskriptif kualitatif, dan penarikan kesimpulan.

Jenis data yang dikumpulkan adalah data ordinal dengan urutan angka 1 sampai dengan 5. Instumen pengumpulan data adalah kombinasi angket terbuka dan angket tertutup. Teknik pengumpulan data melalui cara petugas angket mendatangi responden secara langsung dan setelah selesai diisi dibawa kembali oleh petugas angket. Teknik analisis data melalui penjabaran data, pengelompokkan data, memaknai data dari sudut pandang teori kepuasan kinerja, dan penyimpulan data hasil penelitian.

\section{Hasil dan Pembahasan}

Hasil penelitian dan pembahasan terdiri dari tujuh indikator kepuasan stakeholders atas kinerja lulusan dan tiga indikator harapan stakeholders terhadap kinerja program studi sebagai lembaga pendidikan guru untuk anak usia dini. Ketujuh kepuasan indikator stakeholders atas kinerja lulusan meliputi integritas, profesional, penguasaan bahasa asing, melek teknologi informasi, kemampuan berkomunikasi, bekerjasama, dan pengembangan diri, sedangkan ketiga indikator harapan stakeholders terhadap kinerja program studi meliputi interaksi, lingkungan, dan pengalaman belajar.

Integritas lulusan dalam pandangan para kepala Taman Kanakkanak termasuk sangat baik. 20 orang lulusan memiliki kualitas integritas sangat baik, 18 orang lulusan memiliki kualitas integritas baik, 8 orang lulusan memiliki kualitas integritas cukup, 2 orang lulusan memiliki kualitas integritas kurang, dan tidak satu pun lulusan memiliki kualitas integritas sangat kurang seperti pada Gambar 1.

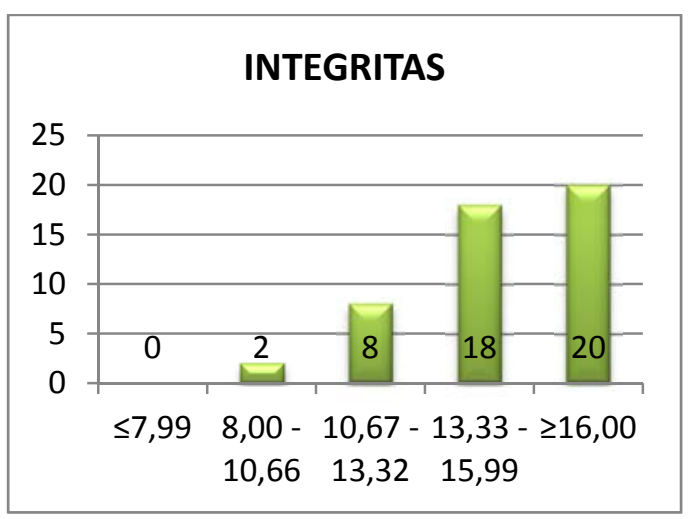

Gambar 1. Kualitas Integritas Lulusan

Profesionalisme lulusan dalam pandangan para kepala Taman Kanakkanak termasuk dalam kategori baik. 20 orang lulusan memiliki kualitas profesionalisme baik, 17 orang lulusan memiliki kualitas profesionalisme cukup, 8 orang lulusan memiliki kualitas profesionalisme sangat baik, 3 orang lulusan memiliki kualitas profesionalisme kurang, dan tidak satu orang pun lulusan memiliki kualitas 
profesionalisme sangat kurang seperti pada Gambar 2.

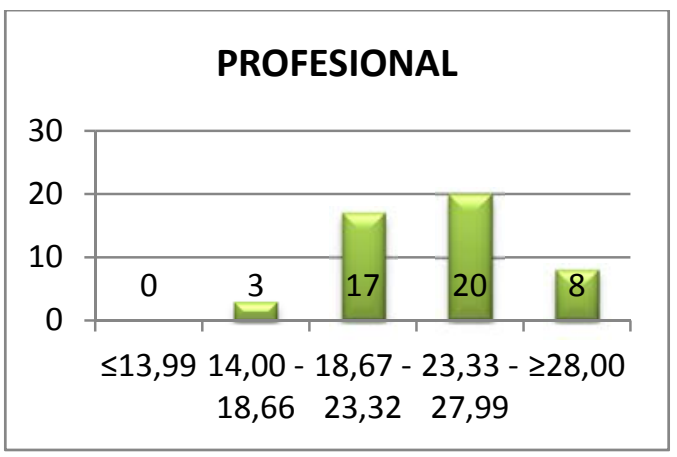

Gambar 2. Kualitas Profesionalisme Lulusan

Pengusaan bahasa asing (Inggris) oleh lulusan dalam pandangan para kepala Taman Kanak-kanak termasuk cukup. 16 orang lulusan menguasai bahasa Inggris dalam kategori cukup, 15 orang lulusan menguasai bahasa Inggris dalam kategori baik, 9 orang lulusan menguasai bahasa Inggris dalam kategori kurang, 7 orang lulusan menguasai bahasa Inggris sangat baik, dan 1 orang lulusan menguasai bahasa Inggris dalam kategori sangat kurang seperti pada Gambar 3.

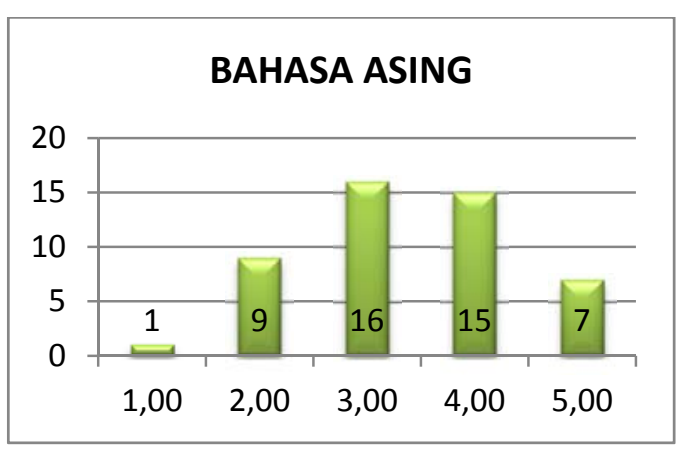

Gambar 3. Penguasaan Bahasa Asing (Inggris)
Penguasaan lulusan terhadap teknologi informasi dalam pandangan para kepala Taman Kanak-kanak termasuk dalam kategori sangat baik. 20 orang lulusan menguasai dan cakap memakai teknologi informasi dengan kategori sangat baik, 16 orang lulusan menguasai dan cakap memakai teknologi informasi dengan kategori cukup, 8 orang lulusan menguasai dan cakap memakai teknologi informasi dengan kategori baik, dan 4 orang lulusan menguasai dan cakap memakai teknologi informasi dengan kategori kurang, dan tidak satu orang lulusan pun yang tidak melek teknologi informasi seperti pada Gambar 4.

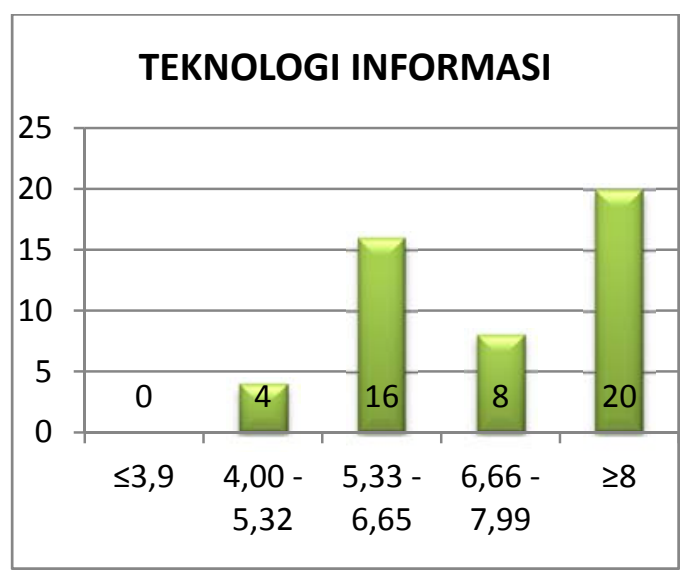

Gambar 4. Penguasaan Teknologi Informasi Lulusan

Kemampuan komunikasi dari lulusan dalam pandangan para kepala Taman Kanak-kanak termasuk dalam kategori cukup. 22 orang lulusan mampu berkomunikasi dalam kategori cukup, 14 orang lulusan mampu berkomunikasi 
dalam kategori sangat baik, 8 orang lulusan mampu berkomunikasi dalam kategori baik, 4 orang lulusan mampu berkomunikasi dalam kategori kurang, dan tidak satu orang pun lulusan masuk dalam kategori sangat kurang mampu berkomunikasi seperti pada Gambar 5.

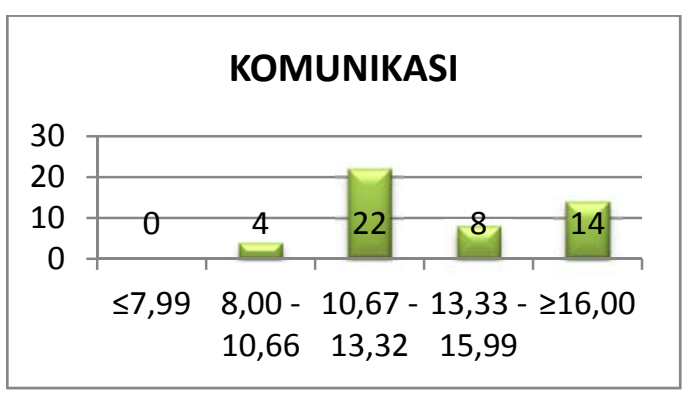

Gambar 5. Kemampuan Berkomunikasi Lulusan

Kemampuan bekerjasama dari lulusan dalam pandangan para kepala Taman Kanak-kanak termasuk dalam kategori cukup. 17 orang lulusan memiliki kemampuan bekerjasama dalam kategori cukup, 13 orang lulusan memiliki kemampuan bekerjasama dalam kategeri sangat baik, 13 orang lulusan memiliki kemampuan bekerjasama dalam kategeri baik, 5 orang lulusan memiliki kemampuan bekerjasama dalam kategeri kurang, dan tidak satu orang pun dari lulusan memiliki kemampuan bekerjasama dalam kategeri sangat kurang seperti pada Gambar 6.

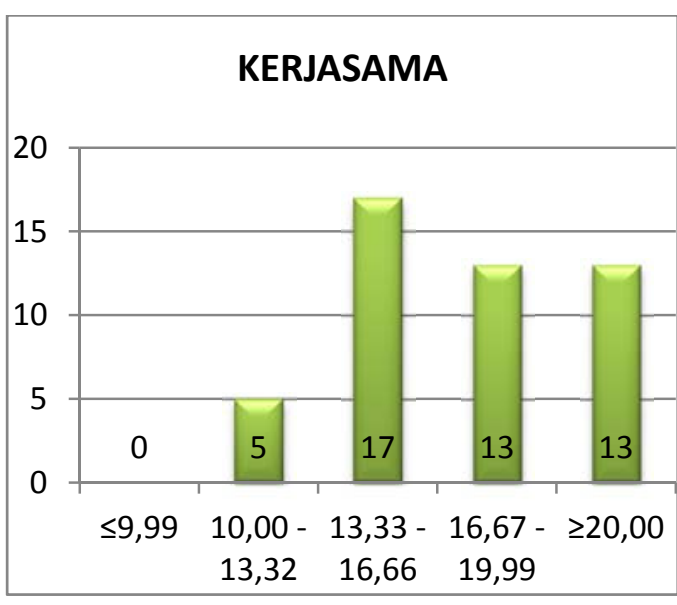

Gambar 6. Kemampuan Bekerjasama Lulusan.

Pengembangan diri lulusan dalam pandangan para kepala Taman Kanak-kanak termasuk dalam kategori baik. 16 orang lulusan memiliki kemampuan mengembangkan diri secara mandiri dalam kategori baik, 14 orang lulusan memiliki kemampuan mengembangkan diri secara mandiri dalam kategori sangat baik, 14 orang lulusan memiliki kemampuan mengembangkan diri secara mandiri dalam kategori cukup, 4 orang lulusan memiliki kemampuan mengembangkan diri secara mandiri dalam kategori kurang, dan tidak seorang pun dari lulusan yang memiliki kemampuan mengembangkan diri secara mandiri dalam kategori sangat kurang seperti pada Gambar 7. 


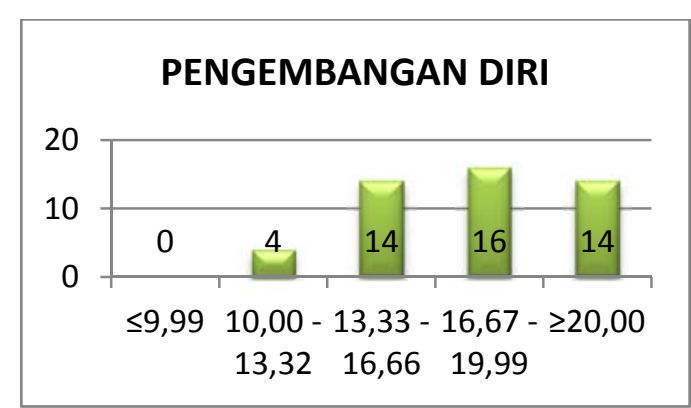

Gambar 7. Pengembangan Diri Lulusan

Secara umum stakeholders merasa puas terhadap kinerja lulusan. Memiliki integritas dan penguasaan teknologi informasi dari lulusan sangat memuaskan para stakeholders. Profesionalisme dalam bekerja dan kemampuan mengembangkan diri secara mandiri dari lulusan memuaskan para stakeholders. Kemampuan bekerjasama, berkomunikasi, dan penguasaan bahasa asing (Inggris) dari lulusan cukup memuaskan para stakeholders.

Harapan stakeholders terhadap kinerja program studi meliputi proses pembelajaran, lingkungan belajar, dan pengalaman belajar. Proses pembelajaran di program studi PGPAUD dalam persepsi lulusan termasuk dalam kategori cukup memuaskan. 15 orang lulusan berpendapat bahwa proses pembelajaran selama kuliah di program studi PGPAUD termasuk dalam kategori cukup memuaskan, 14 orang lulusan berpendapat bahwa proses pembelajaran selama kuliah di program studi
PGPAUD termasuk dalam kategori memuaskan, 12 orang lulusan berpendapat bahwa proses pembelajaran selama kuliah di program studi PGPAUD termasuk dalam kategori sangat memuaskan, dan 7 orang lulusan berpendapat bahwa proses pembelajaran selama kuliah di program studi PGPAUD termasuk dalam kategori kurang memuaskan seperti pada Gambar 8.

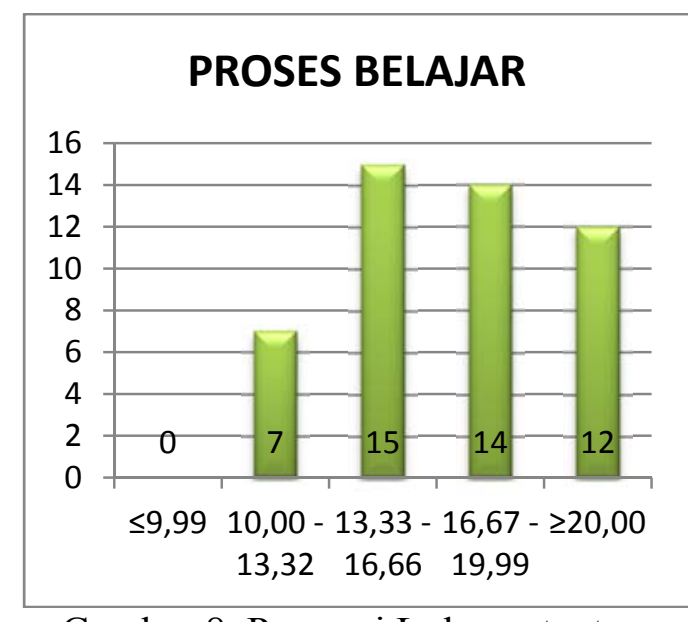

Gambar 8. Persepsi Lulusan tentang Proses Belajar.

Lingkungan belajar di program studi PGPAUD dalam persepsi para lulusan termasuk dalam kategori cukup memuaskan. 19 orang lulusan berpendapat bahwa lingkungan belajar termasuk dalam kategori cukup memuaskan, 16 orang lulusan berpendapat bahwa lingkungan belajar termasuk dalam kategori memuaskan, 7 orang lulusan berpendapat bahwa lingkungan belajar termasuk dalam 
kategori kurang memuaskan, dan 6 orang lulusan berpendapat bahwa lingkungan belajar termasuk dalam kategori sangat memuaskan seperti pada Gambar 9.

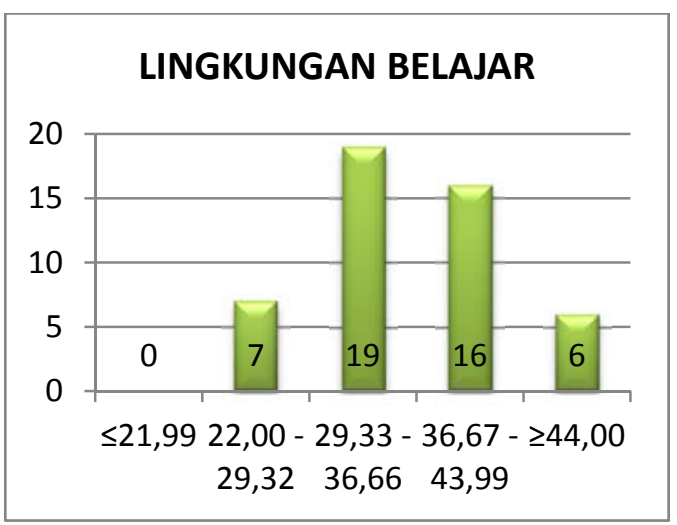

Gambar 9. Persepsi Lulusan tentang Lingkungan Belajar Pengalaman belajar di program studi PGPAUD dalam persepsi lulusan termasuk dalam kategori cukup memuaskan. 21 orang lulusan berpendapat bahwa belajar di program studi PGPAUD cukup memuaskan, 14 orang lulusan berpendapat bahwa belajar di program studi PGPAUD memuaskan, 9 orang lulusan berpendapat bahwa belajar di program studi PGPAUD sangat memuaskan, 3 orang lulusan berpendapat bahwa belajar di program studi PGPAUD kurang memuaskan, dan 1 orang lulusan berpendapat bahwa belajar di program studi PGPAUD sangat kurang memuaskan seperti pada Gambar 10.

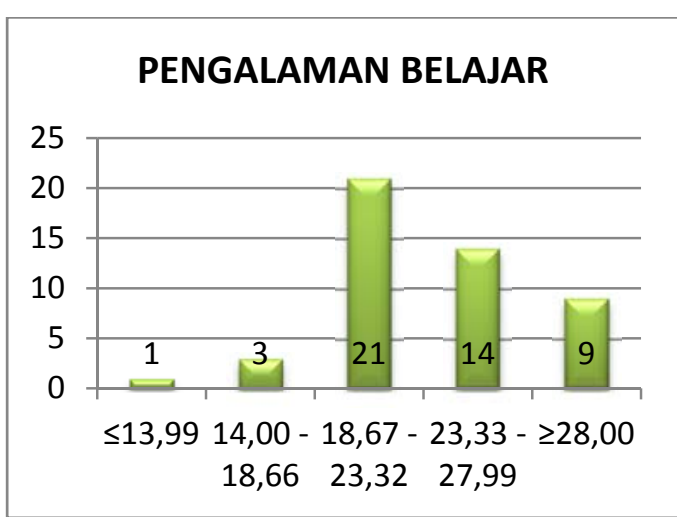

Gambar 10. Persepsi Lulusan tentang Pengalaman Belajar.

Persepsi dari lulusan tentang proses pembelajaran, lingkungan belajar, dan pengalaman belajar termasuk dalam kategori cukup memuaskan. Hal ini diperkuat juga dengan hasil analisis korelasi kompetensi lulusan dengan proses pembelajaran di program studi PGPAUD. Keduanya memiliki skor korelasi positif lebih besar dari 0,5 seperti pada Tabel 1.

Tabel 1. Hasil Korelasi Kompetensi Lulusan dengan Proses Pembelajaran

\begin{tabular}{|l|r|c|c|}
\hline \multicolumn{4}{|c|}{ Correlations } \\
\hline & $\begin{array}{r}\text { Kompe } \\
\text { tensi }\end{array}$ & $\begin{array}{c}\text { Pembel } \\
\text { ajaran }\end{array}$ \\
\hline $\begin{array}{l}\text { Kompet } \\
\text { ensi }\end{array}$ & $\begin{array}{r}\text { Pearso } \\
\mathrm{n}\end{array}$ & 1 &, $583^{* *}$ \\
& $\begin{array}{r}\text { Correl } \\
\text { ation }\end{array}$ & & \\
\hline & $\begin{array}{r}\text { Sig. } \\
(2-\end{array}$ & &, 000 \\
& $\begin{array}{r}\text { tailed } \\
\mathrm{N}\end{array}$ & 48 & 48 \\
\hline & $\begin{array}{r}\text { Pearso } \\
\mathrm{n}\end{array}$ &, $583^{* *}$ & 1 \\
Pembel & $\begin{array}{r}\text { Correl } \\
\text { ajaran }\end{array}$ & \multicolumn{2}{|l}{} \\
\hline
\end{tabular}




\begin{tabular}{|c|c|c|c|}
\hline & $\begin{array}{r}\text { Sig. } \\
(2- \\
\text { tailed) }\end{array}$ &, 000 & \\
\hline . & $\mathrm{N}$ & 48 & 48 \\
\hline
\end{tabular}

Signifikansi hasil korelasi dilakukan dengan cara membandingkan antara $t$ hitung dengan $t$ tabel. Skor $t$ hitung diperoleh sebesar 4,867, sedangkan $t$ tabel sebesar 2,020 (t;0,025;48). Skor t hitung lebih besar dari t tabel, yaitu 4,867>2,020, sehingga dapat disimpulkan ada korelasi antara kompetensi lulusan dengan proses pembelajaran, meskipun korelasinya lemah karena kurang dari 0,5.

Skor maksimal kompetensi lulusan sebesar 82,86 dan skor minimal kompetensi lulusan sebesar 55,00. Penyajian data kompetensi lulusan dibuat menjadi 7 kelas interval dengan jarak interval antar kelas sebesar 5 angka seperti pada Gambar 11.

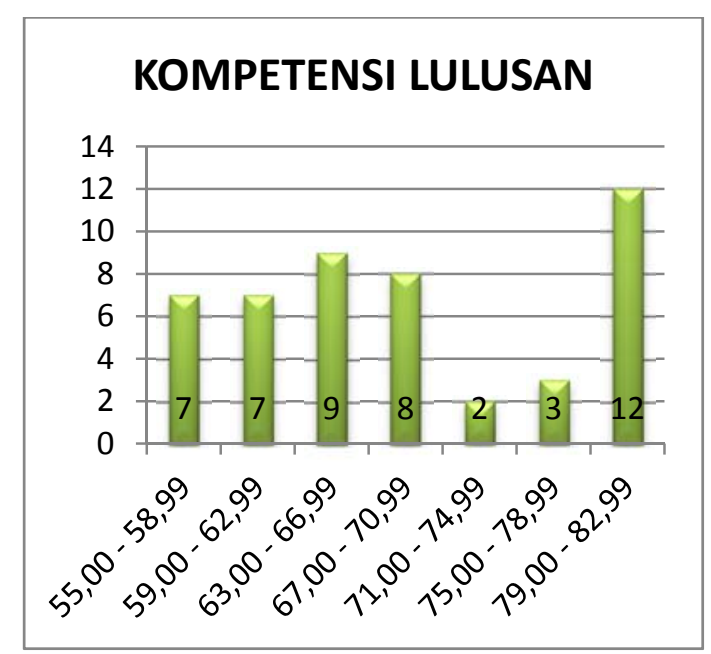

Gambar 11. Kelas Interval Data Kompetensi Lulusan

Skor maksimal data proses pembelajaran sebesar 86,43 dan skor minimal sebesar 52,14. Penyajian data proses pembelajaran dibuat menjadi 7 kelas interval dengan jarak interval antar kelas sebesar 6 angka seperti pada Gambar 12.

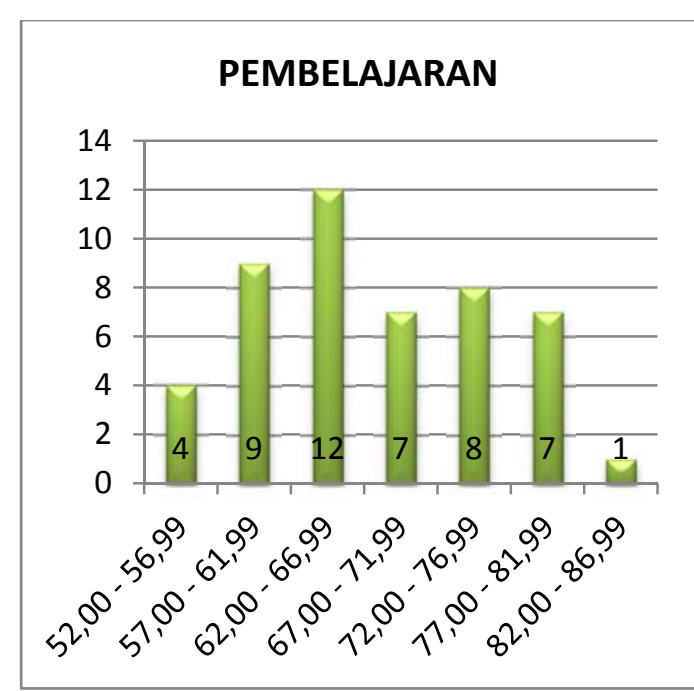

Gambar 12. Kelas Interval Data Proses Pembelajaran

Kedua data tersebut berdistribusi normal sehingga memenuhi syarat untuk analisis korelasi seperti pada Tabel 2. 
Normalitas data dapat dilihat dari indikator skor skewness maupun kurtosis tidak lebih besar dari +2 dan tidak lebih kecil dari -2 .

Tabel 2. Data Statistik Kompetensi Lulusan dan Proses Pembelajaran.

\begin{tabular}{|c|c|c|c|}
\hline \multicolumn{4}{|c|}{ Statistics } \\
\hline $\mathrm{N}$ & $\begin{array}{c}\text { Val } \\
\text { id }\end{array}$ & 48 & 48 \\
\hline Mean & & 68,6458 & 67,5595 \\
\hline $\begin{array}{c}\text { Std. } \\
\text { Deviati } \\
\text { on }\end{array}$ & & 8,50052 & 8,27742 \\
\hline
\end{tabular}

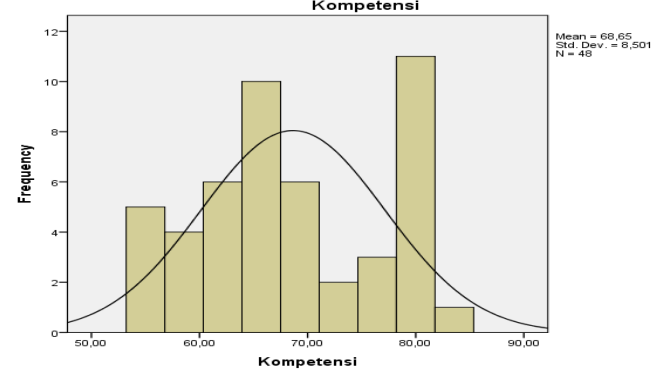

Gambar 13. Histogram Kompetensi Lulusan

Hasil perhitungan skewness dibagi standard error of skewness dari data kompetensi lulusan diperolah angka lebih kecil dari +2 , yaitu 0,150/0,343= 0,437 . Perhitungan kurtosis dibagi standard error of kurtosis dari data kompetensi lulusan diperoleh angka lebih kecil dari -2, yaitu -1,257/0,674 = 1,863. Berdasarkan kedua angka ini, maka dapat disimpulkan bahwa data kompetensi lulusan berdistribusi normal seperti pada Gambar 13.

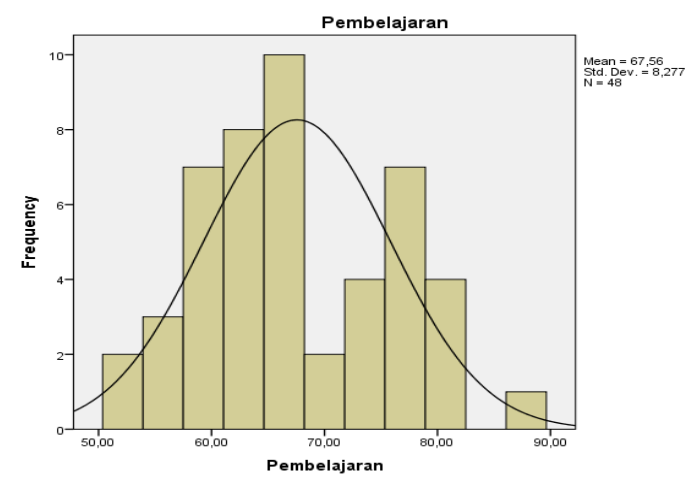

Gambar 14. Histogram Pembelajaran

Hasil perhitungan skewness dibagi standard error of skewness dari data proses pembelajaran diperolah angka lebih kecil dari +2 , yaitu $0,252 / 0,343=0,733$. Perhitungan kurtosis dibagi standard error of kurtosis dari data proses pembelajaran diperoleh angka lebih kecil dari -2, yaitu $0,804 / 0,674=-1,191$. Berdasarkan kedua angka ini, maka dapat disimpulkan bahwa data proses pembelajaran berdistribusi normal seperti pada Gambar 14.

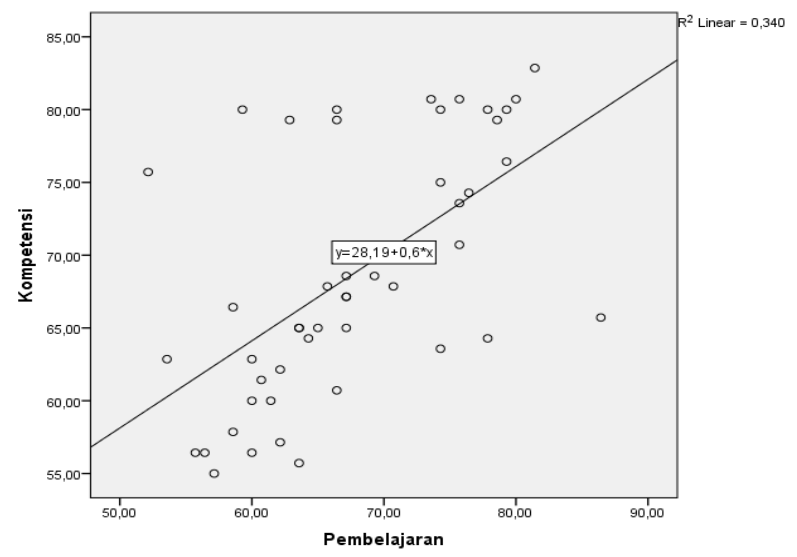

Gambar 15. Scatter Plot Kompetensi Lulusan dan Pembelajaran 
Hubungan antara kompetensi lulusan dengan proses pembelajaran dapat dilukiskan dalam bentuk grafis. Sebaran data dengan masing-masing bulatan menunjukkan satu data yang mengarah ke kanan atas. Hal ini menandakan adanya hubungan yang positif antara kedua variabel, yaitu kompetensi lulusan dan pembelajaran. Pada bagian kanan atas ditampilkan juga skor $\mathrm{R}^{2}$ linear sebesar 0,340. Angka tersebut berasal dari kuadrat indeks korelasi antara variabel kompetensi lulusan dan pembelajaran sebesar 0,583 $\mathrm{x} \quad 0,583=0,340$. Angka tersebut menunjukkan 34\% variabel kompetensi lulusan dapat dijelaskan oleh variabel proses pembelajaran, dan 66\% dijelaskan oleh variabel lain seperti terdapat pada Gambar 15.

\section{Simpulan}

Kepuasan stakeholders terhadap kinerja sebagian besar lulusan sangat memuaskan. Integritas kepribadian dan penguasaan teknologi informasi dari lulusan sangat memuaskan para stakeholders. Profesionalisme dalam bekerja dan kemampuan mengembangkan diri secara mandiri dari lulusan memuaskan para stakeholders. Kemampuan bekerjasama, berkomunikasi, dan penguasaan bahasa asing (Inggris) dari lulusan cukup memuaskan para stakeholders.

Kinerja program studi PGPAUD dalam menyelenggarakan pendidikan dinilai cukup memuaskan oleh sebagaian besar lulusan. Interaksi pembelajaran, lingkungan belajar, dan pengalaman belajar di program studi PGPAUD termasuk dalam kategori cukup memuaskan para lulusan. Ada hubungan positif antara pembelajaran selama kuliah di program studi PGPAUD dengan penguasaan kompetensi oleh lulusan. Bobot hubungan positif tersebut bersifat lemah karena lebih kecil dari kriteria $(0,487<0,500) . \quad$ Variabel kompetensi lulusan dapat dijelaskan oleh variabel pembelajaran sebesar 34\%, dan sisanya dijelaskan oleh faktor lain.

\section{Daftar Pustaka}

Antonius Atosökhi Gea. (2006). Integritas diri: Keunggulan pribadi tangguh, dalam Character building journal, Vol. 3 No. 1, Juli 2006: 16-26.

Dina Rolanna Simanungkalit, Lucy Anna. (2012). Analisis hubungan kerjasama tim untuk meningkatkan efisiensi kerja pada PT Mitha Samudera Wijaya Medan. Dalam jurnal.usu.ac.id/index.php/jmim/ article/download/2340/pdf.

Dzulkifli \& Inda Puspita Sari. (2015). Karakteristik guru ideal. Dalam Seminar Psikologi \& Kemanusiaan (C) 2015 
Psychology Forum UMM, ISBN: 978-979-796-324-8.

Hertina Wulansari, Tuti Hardjajani, Arista Adi Nugroho. (t.t.). Hubungan antara komunikasi yang efektif dan harga diri dengan kohesifitas kelompok pada pasukan supporter solo sejati (Pasoepati). Dalam candrajiwa.psikologi.fk.uns.ac.i $d /$

index.php/candrajiwa/article/do wnload/35/27.

Lydia Ersta Kusumaningtyas. (2015). Dampak overprotektif terhadap perkembangan kemandirian anak. Dalam Widya Wacana. Vol. 10 Nomor 1, Februari 2015.

Masri Singarimbun \& Sofian Effendi (ed.). (1995). Metode penelitian survai. Jakarta: LP3ES. Cetakan 2.

Paul Suparno, SJ. (2015). Integritas pendidikan: Sekolah, guru, dan siswa.

https://repository.usd.ac.id/1263/ 1/1606 20150723+integritas+bs d.pdf.

Pujiyana. (2012). Profesionalisme guru dalam perspektif global. dalam Proceeding Seminar Nasional "Profesionalisme Guru Dalam Perspektif Global” Tahun 2012 ISBN: 978-602-18235-0-7.

Rusi Restiyani, Nengsih Juanengsih, Yanti Herlanti. (2014). Profil pemanfaatan teknologi informasi dan komunikasi (TIK) sebagai media dan sumber pembelajaran oleh guru biologi. Dalam EDUSAINS. Volume VI Nomor 01 Tahun 2014, 50 - 66 .

Singgih Santoso. (2014). Statistik parametrik. Jakarta: Elex Media Komputindo.

Siti Amyani. (2010). Hubungan antara kepercayaan diri dengan kemandirian santri pesantren tahfizh sekolah Daarul Qur'an Internasional Bandung. Skripsi. http://repository.uinjkt.ac.id/dsp ace/bitstream/123456789/21645/ 1/siti\%20amyani-fps.pdf.

Syarifuddin. (2014). Literasi teknologi informasi dan komunikasi. Dalam Jurnal Penelitian Komunikasi. Vol. 17 No.2, Desember 2014: 153-164.

TIM Pengisi Borang. (2015). Borang akreditasi S1 PGPAUD. Yogyakarta: FIP UNY. Tidak diterbitkan.

Wahyu Kusuma Pratiwi dan Dwiarko Nugrohoseno. (2014). Pengaruh kepribadian terhadap kerjasama tim dan dampaknya terhadap kinerja karyawan. Jurnal Ilmu Manajemen. Volume 2 Nomor 3 Juli 2014. 